\title{
POSSIBILITIES OF INFLUENCING THE RESULTS ON PERFORMANCE AND HEALTH OF CALVES WITH BIOPOLYM PREPARAT
}

\author{
Bohuslav ČERMÁK*1, Jana HNISOVÁ*, Eva PETRÁŠKOVÁ*, Kamila \\ PEJCHOVÁ*, Miloslav ŠOCH*, Bohuslav VOSTOUPAL ${ }^{* *}$, Dumitru \\ TUCU $^{* * *}$ \\ *University of South Bohemia in České Budějovice \\ **Bo-algeen, Klokočná - Mnichovice \\ *** Politehnica university of Timisoara, Romania
}

\begin{abstract}
The two farms were conducted experiments with added preparation Biopolym FZT for rearing calves. Additions were applied in the operating conditions where the first farm was gradually calves continuously supplemented to the barn. On the other farm was loading section, and after three months, the calves are picked once. Experimental groups were added preparation Biopolym FZT to supply water for the entire group. The first attempt to farm the results were not significant due to the occurrence of diarrheal disease. In the second company in the experimental group were found higher weight $+0,141 \mathrm{~kg} / \mathrm{day}$ gains than control groups. Between the detected blood parameters in the control and experimental groups was not statistically significant. The results were within the reference range. The tendency Impairment of copper in the blood heifers are similar within the region and in the future could have an adverse effect on reproductive performance. On the data logger ammonia and carbon dioxide, located in the barn were no significant differences in measured values. Values of $\mathrm{N}$-compounds in the feces of calves in both were statistically significant. There was a certain tendency in reducing the average values of $\mathrm{N}$-compounds in experimental groups of calves.
\end{abstract}

Keywords: Calves, Biopolym FZT, weight gain, diarrhea, N-content in waste.

${ }^{1}$ Corresponding author. Mailing adress: University of South Bohemia in the Czech Budejovice, Faculty of Agriculture, Department of Veterinary Sciences and Product Quality, 370 05, Studentská 13, České Budějovice, Czech Republic, Phone: +420 389032 598, email: cermak@zf.jcu.cz 


\section{INTRODUCTION}

In animal feed substance favorably affect the characteristics of feed, improve the performance and durability of animals, promote their reproduction. Due to the frequent issues of ecology and environmental protection is currently trying to use additives derived from nature. In this work was to test the effects of bio-stimulating substances Biopolym FZT on performance and health of rearing calves.

Successful nutrition of ruminants depends on the population and maintaining a healthy and rumen digestive system (Čermák et al., 2011, Gjurov et al., 2007, Perry, 2002, Šoch et al., 1996). Good control of these processes is necessary for the performance and comfort of animals (Šoch et al., 1996, Vostoupal et al., 2005, Vostoupal et al., 2006, Zábranský et al. 2011). When the system, feeding the ruminants actually never feed directly animal, but rumen microflore and only through her target macroorganism

Rumen fermentation provides more than 200 kinds of microorganisms, which are here at a concentration of 150 billion to five ml rumen fluid (Jeroch et al., 1999, Kursa et al., 1998, Matějíček, 2005).

Microbial balance in the digestive tract situational constantly changing especially depending on the composition of the feed. We feed the more fiber, increasing the number of microbes specializing in fiber, add the contrary, carbohydrates, relatively quickly, the composition of microflora changes to spontaneous exploit of carbohydrates (Doležal, 2007, Perry, 2002).

Above all, however, arise as a result of increased infection pressure in herds with a high concentration of animals and wherever technology does not allow for the elementary needs of calves. The main cause of diarrheal diseases, are mixed infections with viruses and bacteria, protozoa and fungi (Illek, 2007, Kursa et al., 1998). Much more frequent and more severe, however, infectious diarrhea that occur in calves weakened, due to dyspepsia or incurred primarily in conditions of poor hygiene, lack of food and the care of calves (Doležal, 2007, Gjurov et al.).

\section{MATERIAL AND METODS}

Calves at vegetable diet in experimental groups were fed twice a day, according to recommendations (Jeroch et al., 1999, Perry, 2002). Application FZT FZT $5 \mathrm{ml} /$ head / day were in plastic drinkers. One day drinkers were thoroughly cleaned. The control and experimental groups of calves were fed the same diet. In the first enterprise in the Region was in control groups 
monitored 68 calves in experimental groups of 88 calves of both gender and origin Czech magpie and the Holstein breed. In the second event in West Bohemia 48 calves and 2 control groups of 52 calves in two experimental groups, with a predominance of breed Czech magpie. Calves were regularly weighed and evaluated weight gain. Records are kept of the number of diseased pieces. The experimental groups were used or only rarely antibiotic agents. Calves control group was treated with the veterinary service by ordinary means (Čermák et al., 2011). For environmental monitoring were placed in each section data logger ammonia and carbon dioxide, placed in each barn. In addition, samples were taken from the rectum of solid excrement calves experimental and experimental groups of seven times during each experiment.

\section{RESULTS AND DISCUSSION}

Under the previous methodology, the average results shown in Tables second. The results represent an increase in weight of a piece in three replications in company $A$ in duplicate in the company B. In each experiment, a company was formed the control group heifers and bulls of 20 . It was confirmed only improve diarrheal conditions without therapeutic agents in experimental groups of calves.

Statistical evaluation of the average growth is significant at the 0.05 level evaluated $\mathrm{T}$ test. Increase in average weight between the first and third weighting.

Tables 2 and 3 give the values of selected blood parameters. In the second, an average gains of calves control groups amounted to $0.771 \mathrm{~kg}$ per head per day, in experimental $0.912 \mathrm{~kg} /$ head per day. Treatment of calves in experimental groups was not needed. The results suggest that the experimental calves reached better performance characteristics, than the control group. These results in the first enterprise should serve to regulate mineral nutrition, because in terms of calcium magnesium and copper in both groups, the data below the reference values for calves. In the control group is also reflected by zinc deficiency. The data, especially the higher incidence of diarrheal disease shows significant problems with addiction microflora in continuous stocking calves (Čermák et al., 2011, Illek, 2007)

Tables 2 and 3 give the values of selected blood parameters. In the second, an average gains of calves control groups amounted to $0.771 \mathrm{~kg}$ per head per day, in experimental $0.912 \mathrm{~kg} /$ head per day. Treatment of calves in experimental groups was not needed. 
The results suggest that the experimental calves reached better performance characteristics, than the control group. These results in the first enterprise should serve to regulate mineral nutrition, because in terms of calcium magnesium and copper in both groups, the data below the reference values for calves. In the control group is also reflected by zinc deficiency. The data, especially the higher incidence of diarrheal disease shows significant problems with addiction microflora in continuous stocking calves (Čermák et al., 2011, Illek, 2007)

Table 1. Results of calves weight

Farm A Farm B

\begin{tabular}{|c|c|c|c|c|c|c|c|}
\hline \multirow{3}{*}{$\begin{array}{c}\text { Live } \\
\text { weight } \\
(\mathrm{kg}) \\
\end{array}$} & \multirow{2}{*}{\multicolumn{3}{|c|}{ Experimental groups }} & & \multicolumn{3}{|c|}{$\begin{array}{l}\text { Live weight at born } \\
(\mathrm{kg}) \text { diarhea }\end{array}$} \\
\hline & & & & \multirow[t]{2}{*}{ groups } & $\mathrm{n}$ & $\bar{\xi}$ & 2 \\
\hline & $\mathrm{n}$ & $\begin{array}{c}\bar{\xi} \\
(\mathrm{kg})\end{array}$ & $\mathrm{s}_{\mathrm{x}}$ & & 19 & 43.4 & 3 \\
\hline at born & 72 & 46.4 & 7,7 & control & 19 & 46.6 & 5 \\
\hline \multirow[t]{6}{*}{ in 120 day } & 61 & 196.0 & 27,5 & \multirow[t]{2}{*}{ experiment } & \multirow{2}{*}{\multicolumn{2}{|c|}{ in 120 day }} & \multirow{3}{*}{$\mathrm{T}$ test } \\
\hline & \multicolumn{3}{|c|}{ Control groups } & & & & \\
\hline & $\mathrm{n}$ & $\bar{\xi}$ & $S_{x}$ & & $\bar{\xi}$ & $\mathrm{s}_{\mathrm{x}}$ & \\
\hline & & $(\mathrm{kg})$ & & & 187.0 & 187.0 & \\
\hline & 68 & 46.3 & 7,5 & & \multirow[t]{2}{*}{199.8} & \multirow[t]{2}{*}{199.8} & \\
\hline & 61 & 183.2 & 25,4 & & & & $*+12,8 \mathrm{~kg}$ \\
\hline
\end{tabular}

legend: $\mathrm{n}=$ number, $\mathrm{x}=$ asverage, $\mathrm{sx}=$ standard deviation

Between the detected blood parameters in the control and experimental groups was not statistically significant. The results were within the reference range. The tendency Impairment of copper in the blood heifers are similar within the region and in the future could have an adverse effect on reproductive performance.

Values of $\mathrm{N}$-compounds in the feces of calves in both companies in evaluating samples of feces weighing fluctuated and were statistically significant (Čermák et al., 2011, Čermák et al., 2011, Kursa, 1998). There was a certain tendency in reducing the average values of $\mathrm{N}$-compounds in experimental groups of calves. 
Table 2. Chossen blod parameters of calves in experimental groups

\begin{tabular}{|c|c|c|c|c|c|c|}
\hline & Glyk & Urea & $\mathrm{AF}$ & $\mathrm{CB}$ & Chol. & triglyc. \\
\hline & $\mathrm{mmol} / \mathrm{l}$ & $\mathrm{llol} / \mathrm{l}$ & $\mathrm{ukat} / \mathrm{l}$ & $\mathrm{g} / \mathrm{l}$ & $\mathrm{mmol} / \mathrm{l}$ & $\mathrm{mmol} / \mathrm{l}$ \\
\hline average & 4,00 & 3,43 & 2,39 & 73,11 & 2,71 & 0,1 \\
\hline $\begin{array}{c}\text { st.deviati } \\
\text { on. }\end{array}$ & 0,49 & 0,54 & 0,90 & 6,72 & 0,67 & 0,03 \\
\hline $\min$ & 3,38 & 2,45 & 1,43 & 64,60 & 1,87 & 0,06 \\
\hline $\max$ & 4,95 & 4,14 & 4,15 & 84,90 & 4,04 & 0,17 \\
\hline
\end{tabular}

Reference value of authors Šoch( 2011)

\begin{tabular}{|l|l|l|l|l|l}
3,50 & $3,0-5,0$ & $0,6-3,0$ & $65-75$ & $2,6-5,2$ & 0,80 \\
\hline
\end{tabular}

\begin{tabular}{|c|c|c|c|c|}
\hline $\mathrm{P}$ & $\mathrm{Ca}$ & $\mathrm{Mg}$ & $\mathrm{Zn}$ & $\mathrm{Cu}$ \\
\hline $\mathrm{mmol} / \mathrm{l}$ & $\mathrm{mmol} / \mathrm{l}$ & $\mathrm{mmol} / \mathrm{l}$ & $\mathrm{mmol} / \mathrm{l}$ & $\mathrm{mmol} / \mathrm{l}$ \\
\hline 2,54 & 2,12 & 0,68 & 12,83 & 10,93 \\
\hline 0,26 & 0,10 & 0,12 & 2,53 & 1,58 \\
\hline 1,91 & 1,91 & 0,40 & 9,33 & 8,49 \\
\hline 2,80 & 2,24 & 0,81 & 16,52 & 14,32 \\
\hline
\end{tabular}

Table 3a. Chossen blod parameters of calves in control group

\begin{tabular}{|c|c|c|c|c|c|c|}
\hline & Glyk & Urea & $\mathrm{AF}$ & $\mathrm{CB}$ & Chol. & triglyc. \\
\hline & $\mathrm{mmol} / \mathrm{l}$ & 1lol/1 & ukat/1 & $\mathrm{g} / \mathrm{l}$ & $\mathrm{mmol} / \mathrm{l}$ & $\mathrm{mmol} / \mathrm{l}$ \\
\hline average & 3,83 & 3,77 & 2,46 & 64,95 & 2,37 & 0,1 \\
\hline $\begin{array}{c}\text { st.deviatio } \\
\mathrm{n}\end{array}$ & 0,38 & 0,68 & 0,76 & 9,89 & 0,57 & 0,05 \\
\hline $\min$. & 2,94 & 2,56 & 1,55 & 45,5 & 1,4 & 0,02 \\
\hline $\max$ & 4,58 & 4,79 & 3,92 & 78,5 & 3,51 & 0,19 \\
\hline \multicolumn{7}{|c|}{ Reference value of authors Šoch (2011) } \\
\hline & 3,5 & $3,0-5,0$ & $0,6-3,0$ & $65-75$ & $2,6-5,2$ & 0,8 \\
\hline
\end{tabular}


Table 3b. Chossen blod parameters of calves in control groups

\begin{tabular}{|c|c|c|l|c|}
\hline $\mathrm{P}$ & $\mathrm{Ca}$ & $\mathrm{Mg}$ & $\mathrm{Zn}$ & $\mathrm{Cu}$ \\
\hline $\mathrm{mmol} / \mathrm{l}$ & $\mathrm{mmol} / \mathrm{l}$ & $\mathrm{mmol} / \mathrm{l}$ & $\mathrm{mmol} / \mathrm{l}$ & $\mathrm{mmol} / \mathrm{l}$ \\
\hline 2,51 & 1,97 & 0,69 & 11,77 & 11,77 \\
\hline 0,5 & 0,23 & 0,11 & 1,62 & 1,62 \\
\hline 1,95 & 1,58 & 0,53 & 8,97 & 8,97 \\
\hline 3,4 & 2,33 & 0,94 & 14,16 & 14,16 \\
\hline $\begin{array}{l}\text { Reference value of authors } \\
\text { Soch (2011) }\end{array}$ & & & \\
\hline $1,6-2,26$ & $2,25-3,0$ & $0,8-1,07$ & $12,6-18,9$ & $12,16-18,9$ \\
\hline
\end{tabular}

Table 4. Content of crude protein in waste

\begin{tabular}{|l|c|c|c|c|}
\hline Sample & Avererae & Stand. deviation & min & MAX \\
\hline KA & 10,386 & 0,416 & 9,68 & 11,1 \\
\hline P1A & 10,258 & 0,439 & 9,65 & 10,98 \\
\hline P2A & 10,13 & 0,462 & 9,62 & 10,95 \\
\hline P3A & 9,88 & 0,605 & 9,08 & 10,95 \\
\hline P4A & 9,944 & 0,258 & 9,66 & 10,33 \\
\hline KB & 11,12 & 0,508 & 10,45 & 11,9 \\
\hline PJB & 10,682 & 0,546 & 9,75 & 11,45 \\
\hline PJB & 10,87 & 0,394 & 10,3 & 11,4 \\
\hline
\end{tabular}

Legend: Average of 8 number of each sample place s (KA and other) Farm A, B. Table 4.

Treated calves attempt to control 7 days 9 days on the data logger ammonia and carbon dioxide, located in the barn were no significant differences in measured values. Confirmed a reduction of ammonia in the environment given by the manufacturer quotes (Gjurov, 2007, Vostoupal et al., 2006), because each one wall stables was permanently opened.

\section{CONCLUSIONS}

Verification preparation Biopolym FZT calves showed a slight increase in increments experimental groups of calves in the first company. In other business, the increase of $+0.141 \mathrm{~kg} /$ head per day. Somewhat worse results in the first business related to continuous stocking calves into the barn.

Vol. XVII (2013), no. 2 
Between the detected blood parameters in the control and experimental groups was not statistically significant. The results were within the reference range. The tendency Impairment of copper in the blood heifers are similar within the region and in the future could have an adverse effect on reproductive performance. On the data logger ammonia and carbon dioxide, located in the barn were no significant differences in measured values. Values of $\mathrm{N}$-compounds in the feces of calves in both companies were statistically significant. There was a certain tendency in reducing the average values of $\mathrm{N}$-compounds in experimental groups of calves.

\section{ACKNOWLEDGMENTS}

This article was written during realization of the project NAZV QJ1210144 and GAJU 020/2013/Z.

\section{REFERENCES}

1. Čermák, B., Kubát, V., Šoch, M., Hnisová, J., Petrášková, E., Zábranský, L.,Vostoupal, B. (2011). Možnosti využití doplňku Biopolymu v prevenci a posílení zdraví telat a vykrmovaného skotu. Certifikovaná metodika., 28 s. ISBN 978-80-7394-324-4.

2. Čermák, B., Hnisová, J., Petrášková, E., Kubát, V., Šoch, M., Vostoupal, B. (2011). Možnosti ovlivnění výsledků užitkovosti a zdraví telat preparátem Biopolym. In: Sborník z mezinárodní konference „Aktuální otázky bioklimatologie zvírat“. 7. 12. 2011 ČHMU Brno, s. 25 - 27. ISBN 978-80-7403-086-4.

3. Doležal, O. (2007). Péče o novorozené tele. Náš chov, č. 9, s. $26-31$.

4. Gjurov, V., Šoch, M., Vostoupal, B., Vráblíková, J., Zajíček, P., Novák, P. (2007). Využití biotechnologických přípravků. Sborník z mezinárodní vědecké konference „Výzkum moderných technológií... “ konané v Nitře (SR) dne 11. 9., s. 16-30, SPU v Nitre, ISBN 978-80-8069-928-4.

5. Illek, J. (2007). Závažná průjmová onemocnění telat. Zemédělec: Odborný a stavovský týdeník. 7. 5. 2007, roč. XV, č. 19, s. 9 - 12.

6. Jeroch, H. et al. (1999). Ernährung landwirtschaftlicher Nutztiere. Stuttgart, UTB Ulmer, $544 \mathrm{~s}$.

7. Kursa, J. a kol. (1998). Zoohygiena a prevence chorob hospodářských zvírat., ZF JU České Budějovice, $200 \mathrm{s.}$

8. Matějíček, M. (2005). Bachorové dysfunkce - nejvýznamnější produkční choroby dojnic. VVS Verměřovice, $62 \mathrm{~s}$.

9. Perry, T. W. (2002). Feed Formulations. Danville, Illinois, USA, The Interst. Print. and Publish. 380 s. 
10. Šoch, M., Novák, P., Kratochvíl, P. (1996). Vliv změn technologie chovu a krmení na fyziologické funkce a welfare telat. Sborník ze 3. ročníku odborného semináře s mezinárodní účastí „Ochrana zvírat a welfare“. VFU Brno, str. 50 - 51, ISBN 80-86020-061.

11. Vostoupal, B., Šoch, M., Novák, P., Gjurov, V., Jelínek, A., Dědina, M., Plíva, P. (2005). Možnosti dílčí účelové sanace bioklimatu venkovských sídel použitím připravkủ bio-algeenové řady. VÚŽV Praha, ČHMU Brno, 13. prosince 2005, s. $105-108$.

12. Vostoupal, B., Jelínek, A., Plíva, P., Dědina, M., Gjurov, V. (2006). Bioalgináty v roli významného detoxikačního média. Sborník příspěvků z 6. konference s mezinárodní účastí konané na téma „Využití doplňkové a nekonvenční péče o zdraví zvířat“, ZF JU České Budějovice, 16. - 17. 6. 2006., s. $138-144$.

13. Zábranský, L., Šoch, M., Št’astná, J., Líbalová, K., Raabová, M., Benda, M., Peksa, Z., Volfová, K., Tejml, P., Podlahová, Š. (2011). Možnosti využití nekonvenčních postupů a potravních doplňků v prevenci a péči o zdraví telat. In: Sborník z mezinárodní konference „Aktuální otázky bioklimatologie zvírat" 7. 12., ČHMU Brno, s. 118 - 121. 24 ISBN 97880-7403-086. 